\title{
Erratum to: Methoxyflurane: A Review in Trauma Pain
}

\author{
Hannah A. Blair ${ }^{1} \cdot$ James E. Frampton $^{1}$
}

Published online: 17 November 2016

(c) Springer International Publishing Switzerland 2016

\section{Erratum to: Clin Drug Investig \\ DOI 10.1007/s40261-016-0473-0}

In the original publication, one of the reviewer's names in the reviewer listing is incorrect. The name of the third reviewer, which previously read as "E. Nausheen" should read as "N. E. Doctor".

The online version of the original article can be found under doi: 10.1007/s40261-016-0473-0.

Hannah A. Blair

demail@springer.com

1 Springer, Private Bag 65901, Mairangi Bay, 0754 Auckland, New Zealand 